\title{
動翼を用いた観測ロケットの適応型姿勢制御系の設計と ハードウェア試験*1 \\ Design and Hardware Verification of Canard Based Sounding Rocket Attitude Controller Using Adaptive Filter
}

\author{
澤 井 秀 次 郎 ${ }^{* 2} \cdot$ 松 田 聖 路*3 \\ Shujiro Sawai and Seiji Matsuda
}

Key Words: Rockets, Attitude Control, Canard, Adaptive Control

\begin{abstract}
Canard based controller using an adaptive notch filter is proposed to control the attitude of launch vehicles including the ISAS's sounding rocket 'S-520'. As the characteristics of launch vehicles are time variant in nature, conventional time invariant controller is not suitable for this purpose. Here, adaptive notch filter is proposed to treat the time variant nature. This adaptive filter acts to null out the structural bending mode, which often causes the instability of the attitude controller. The proposed adaptation law requires only limited calculation cost. It means that it is easy to install to the real flight system. The hardware module which aims to control the attitude of the sounding rocket ' $\mathrm{S}-520$ ' is designed and verified not only by the numerical simulations, but also by the hardware tests.
\end{abstract}

\section{1.はじめに}

ロケットの種類には , 衛星などを軌道に投入する大型の ロケットの他に, 比較的短時間の弾道飛行をする小型の観 測ロケットがある ${ }^{1,2)}$.観測ロケットは比較的低いコストで 短期間の準備で打ち上げができることにより，たとえば弾 道飛行をする数分の間に上層大気の観測を行ったり，衛星 搭載用新規技術の実証試験を行うなどの用途で利用されて いる・ところが近年, これらの観測ロケットの利用目的が 多樣化するにつれて飛翔軌道の精度要求は厳しくなる傾向 にあり，利用目的によっては推力飛行時の姿勢制御を積極 的に行う必要性が出始めている. 推力飛行中の姿勢制御を 行うことで推力方向が制御されるので，搭載ペイロード動 作中の軌道分散が小さくると同時に, 弾道飛行を終えた ロケットの落下点分散も小さくすることができる .これに より，従来は落下点分散が大きすぎて採用することができ なかった軌道を飛翔させることができるようになるなど， 推力飛行中の積極的姿勢制御の採用は利用目的の多樣化に 寄与する.

積極的な姿勢制御に対応するため, 観測ロケットに簡単 に取り付けられる動翼システムの開発が考えられている3,4). 第 1 図に乥の概観図を示す .この動翼システムは, 宇宙科 学研究所の $S-520$ 型観測ロケットへの搭載を前提に, 固体 推薬のロケットモータと, 利用目的に応じてユーザが用意 するミッション機器部の間に挿入されるような形態である． このようにすることで, 既存のインターフェースをほとん ど変更することなく観測ロケットへの姿勢制御系組み込み

${ }^{* 1}$ C2002 日本航空宇宙学会

平成 14 年 1 月 24 日原稿受理

*2 宇宙科学研究所

*3 (株) アイ・エイチ・アイ・エアロスペース
が可能になる .

本稿では, まず，このようなユニット化された動翼シス テムのハードウェア構成を概説し, 兴の後, この動翼シス テムのために開発された制御則について論ずる．本稿は文 献3〜4）で著者らか提案した制御則を拡張し，さらに光れ をハードウェア試作，試験により検証している こここで,制 御則は, 機体特性の変化に対応できるような適応型制御系 である。

\section{2. 動翼システムのハードウェア構成}

開発した動翼システムは, 第 2 図に示すような円筒形状 の周囲 4 力所に翼が付いたものである . 翼はチタン合金製 で, 兴の舵角は 4 台のサーボモータにより 4 翼独立に制御 される.モ一タの電力は, 円筒内部の熱電池から供給され る.さらに ,この円筒内にはジャイロ，制御計算機が搭載 されており，動翼の舵角指令值を算出している．

この円筒部分は, 既存の $\mathrm{S}-520$ 型観測ロケットのモータ 部と頭胴部の間に挿入される、頭胴部は, ユーザが利用す るペイロード部であり，打ち上げ目的に応じて，光の中身 は変化する，一方，モータ部は設計が固定されており，打 ち上げ目的にかかわらず，ほぼ毎回同一である . 開発した 動翼部は, モータ部と頭胴部の間に挿入することで, 既存 のシステムへのインパクトを最小限に抑えることを意図し ている.第 1 表に主要諸元を揭げる.

\section{3. 動翼制御系の設計}

一般にロケットの姿勢制御においては, ロケットを剛体 と近似したときの全体的な姿勢を誘導指令值に追従させる とともに, ロケットの姿勢制御系が構造振動を過度に励起 しないように注意する必要がある．しかしながら，ロケッ 
宇宙技術 第 1 巻 （2002 年） 9404

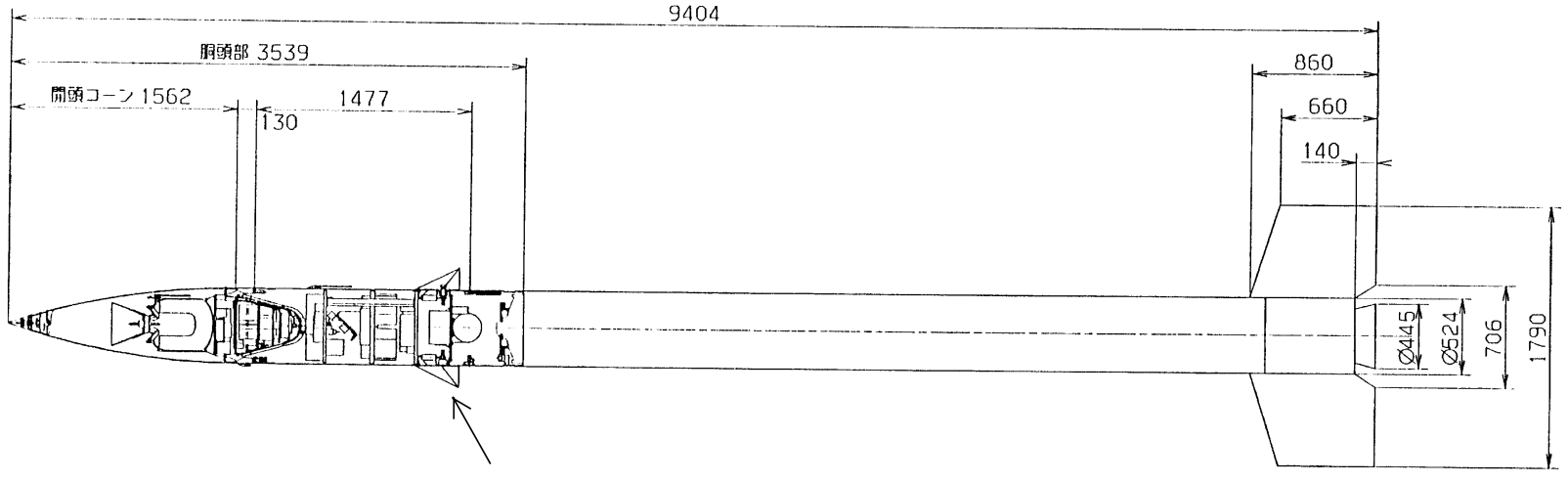

第1図＼cjkstart動翼付き観測ロケットの例

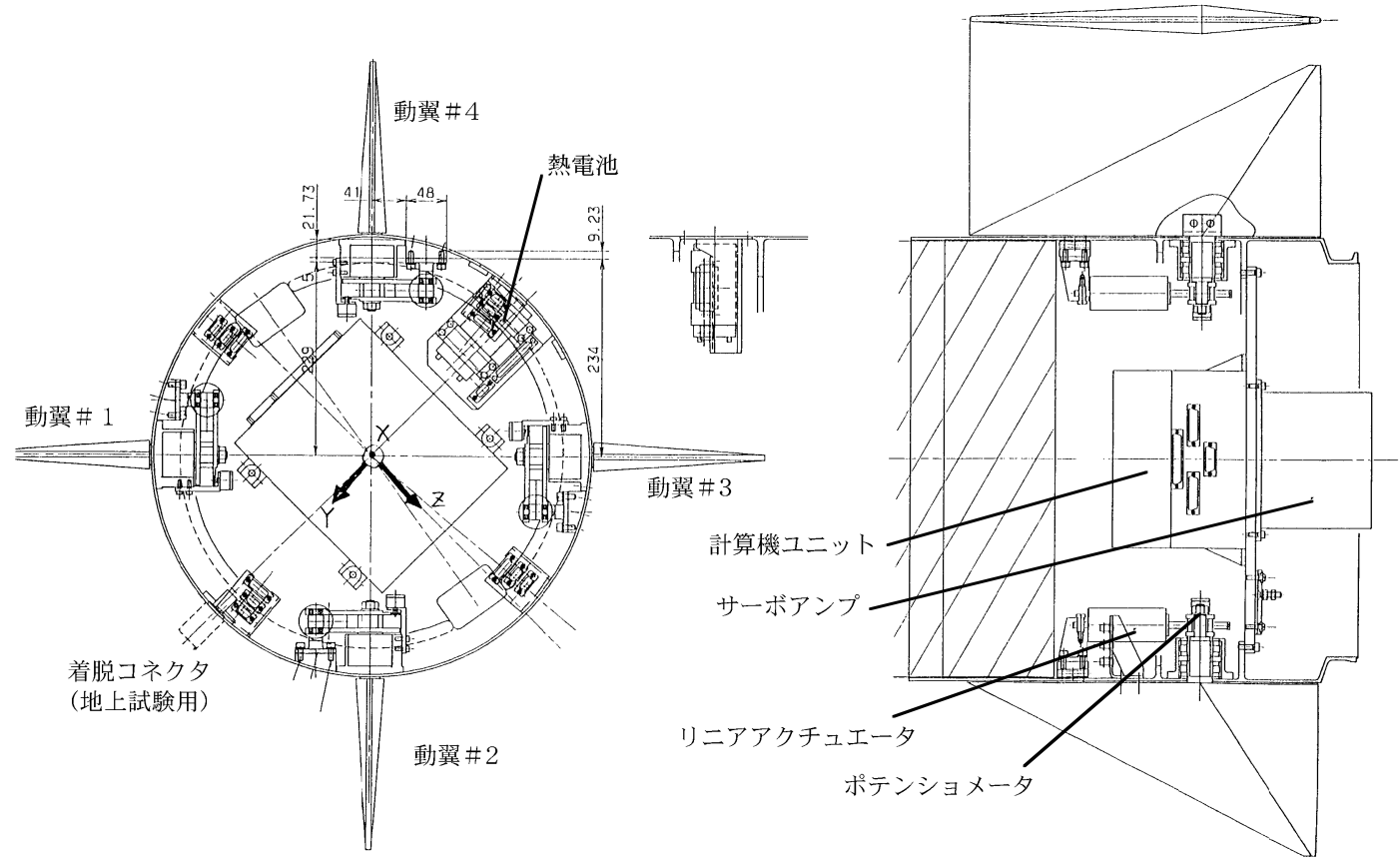

第 2 図試作した動翼制御システムの概略図

卜の動特性は飛翔中に大きく変化し, 構造振動の固有振動 特性なども時間とともに変化する (第3図参照).すなわち， 本質的にロケットの姿勢ダイナミクスは時変系である．し かし，二れを直接扱うのが困難であるため，従来の制御系 設計法としては，たとえばある瞬間の特性に固定した制御 系をいくつか用意し，产れを時間とともに切り替える，と いったような手法がとられてきだ5) ささらにこの構造振動の 特性は, 搭載するミッション機器の重量特性, 構造特性に も依存する .すなわち, 制御則の設計は, 個々のロケット ごとに調整する必要がある.

弚れに対して，本稿では適応型のノッチフィルターを用 いて, 時間とともに変動していく構造振動の特性に動的に 適応しつつ制御することを考えた . 提案する適応型のノッ チフィルターは, ノッチフィルターの中心周波数を構造振 動の周波数へと適応させていくことにより，一種の適応才 ブザーバとみなすこともできる．この適応性によって，時
間とともに変化する特性に制御出力を調整し，安定性を保 ちつつ，高い追従性を達成することを目指している。

ノッチフィルターとは，ある特定の周波数帯域のゲイン を落とすようなフィルターである．今の場合，モデル化誤 差の影響が大きい構造の 1 次振動モードの周波数帯域での ゲインを落とすようなフィルターを制御器に付加すること で，1 次モードの励振を避けることを意図している．制御 系を構筑する目的は, 制御対象のモデルが不確かな場合に も，より高い目標追従性と安定性を確保することにある． ロケットの姿勢制御の問題においては, 特に高い追従性能 が要求されるのはロケット推力方向に直接の影響を与える 剛体モードの姿勢である。構造振動のモード周波数付近の 帯域は, 光れ自体単独では高い追従性能を要求されていな い一方で，モデル化誤差の影響を受けやすく，系の安定性 に大きな影響を及ぼす．よって，モデル化誤差の影響を低 減させるため，従来，制御帯域を 1 次の構造振動モードよ 
動翼を用いた観測ロケットの適応型姿勢制御系の設計とハードウェア試験（澤井秀次郎・松田聖路）

第1表 試作した動翼システムの主要諸元

\begin{tabular}{|c|c|c|}
\hline 項目 & 仕樣 & 備考 \\
\hline 重量 & $52.0 \mathrm{~kg}$ & \\
\hline 主要部寸法 & 直径 $520 \mathrm{~mm} \times$ 高さ $538 \mathrm{~mm}$ & · 円筒形状 \\
\hline 動翼枚数 & 4 枚 & $\begin{array}{l}\text { ·高さ } 424 \mathrm{~mm} \times \text { 長さ } 214 \mathrm{~mm} \text { の直角三角形形状 } \\
\text { • 円筒部の周囲に } 90 \text { 度おきに設置 } \\
\text { • チタン合金製 }\end{array}$ \\
\hline 連続動作時間 & 30 秒以上 & ・電源系 (熱電池) としては 40 秒以上の動作 \\
\hline 電源系 & $\begin{array}{l}+18 \mathrm{~V} \text { 系: } 2 \mathrm{~A} \text { 以上 (信号処理用) } \\
-18 \mathrm{~V} \text { 系 : } 2 \mathrm{~A} \text { 以上 (信号処理用) } \\
+28 \mathrm{~V} \text { 系 : } 5 \mathrm{~A} \text { 以上 (動翼駆動用) } \\
\text { 熱電池表面温度 : 約 } 300{ }^{\circ} \mathrm{C} \\
\text { 熱電池立ち上がり時間 }: 1 \text { 秒以下 }\end{array}$ & 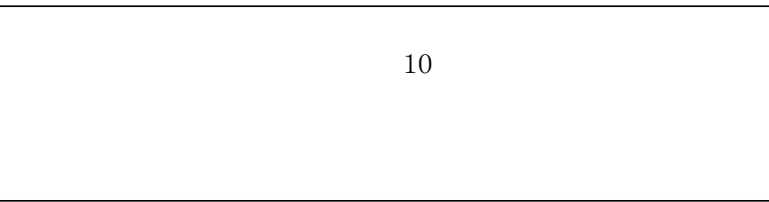 \\
\hline 動翼部アクチュエータ & $\begin{array}{ll}\text { 振幅 } & : 5 \mathrm{deg} \\
\text { 応答周波数 } & : 7 \mathrm{~Hz}\end{array}$ & ・電動リニアアクチュエータとサーボモータで構成 \\
\hline $\begin{array}{l}\text { 姿勢計測 } \\
\text { (ピツチ・ヨー) }\end{array}$ & $\begin{array}{ll}\text { 角速度範囲 } & : \pm 100 \mathrm{deg} / \mathrm{s} \\
\text { レート計測直線性 } & : 0.1 \% \text { 以下 } \\
\text { 応答周波数 } & : 20 \mathrm{~Hz} \text { 以上 } \\
\text { ランダムドリフト } & : 20 \mathrm{deg} / \mathrm{h}(1 \sigma) \\
\mathrm{G} \text { 感ドリフト } \quad: 10 \mathrm{deg} / \mathrm{h} / \mathrm{g}\end{array}$ & ・3軸レートジャイロ使用 \\
\hline $\begin{array}{l}\text { 姿勢計測 } \\
\text { (ロール) }\end{array}$ & $\begin{array}{ll}\text { 角速度範囲 } & : \pm 720 \mathrm{deg} / \mathrm{sec} \\
\text { レート計測直線性 } & : 0.1 \% \text { 以下 } \\
\text { 応答周波数 } & : 20 \mathrm{~Hz} \text { 以上 } \\
\text { ランダムドリフト } & : 50 \mathrm{deg} / \mathrm{h}(1 \sigma) \\
\mathrm{G} \text { 感ドリフト } & : 40 \mathrm{deg} / \mathrm{h} / \mathrm{g} \\
\end{array}$ & ・3軸レートジャイロ使用 \\
\hline $\begin{array}{l}\text { 主要タイマ項目 } \\
\text { (ノミナル・シーケンス) }\end{array}$ & $\begin{array}{ll}X-10 \text { 秒 } & \text { 熱電池点火 } \\
X-7 \text { 秒 } & \text { 疑似操舵開始 } \\
x-1 \text { 秒 } & \text { 姿勢制御開始 } \\
x+25 \text { 秒 } & \text { ロール制御開始 } \\
x+30 \text { 秒 } & \text { 制御停止 } \\
\end{array}$ & $\begin{array}{l}\cdot x-7 \text { 秒の疑似操舵はフライト前最終確認のため実施 } \\
\cdot x+25 \text { 秒のロール制御の目標值は搭載機器からの要求に基づき } \\
\text { 決定される } \\
\text { (注) } x: \text { 打ち上げ時刻 }\end{array}$ \\
\hline
\end{tabular}

り低くとるなどの方策がとられることがあった .

ロケットの姿勢制御などにおいて, 構造振動などの高い 周波数の固有振動を無視した設計を行うと，「スピルオー バー」と呼ばれる現象の影響で結果として系全体が不安定 化することがある .この「スピルオーバー」を回避するた め, 制御系の帯域を, 構造振動の周波数などと比較して十 分に低く制限するのが有効であることが知られている。し かし，光の一方で, 目標への追従性，すなわち応答性を上 げるためには,より広い制御帯域が必要となる。「スピル オーバー」を回避するため，制御系の帯域を制限して，高 い周波数をゲイン安定化させると, 制御系の応答性が劣化 する．このため，たとえば 1 次の構造振動モードを超えた

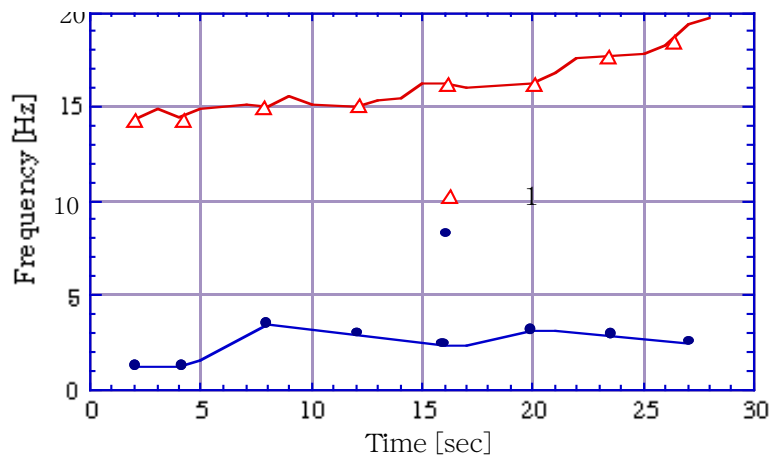

第3图 ロケット機体特性の時間变化の例 (S-520-15 号機飛翔データ)
帯域を確保することか望ましい場合も出てくる．炎のよう なときにも系の安定性を確保する手段のひとつとして ,1次 の構造振動モードの帯域 (モデル化誤差により不安定化し やすい制御帯域) をカットした制御帯域を確保することが 考えられる.すなわち, 得られた制御入力を, 不安定要因 になりうる帯域をカットするノッチフィルターを通して制 御対象に与える，という制御方式である.特にロケットの 姿勢制御の場合, 構造振動は光れ自体では安定であり，か つ制御の必要性が低い, 兴のため, 不確定な構造振動モ一 ドに対応する周波数域の制御ゲインをノッチフィルターに よって意图的に小さくして安定性を確保するとともに，口 ケットの姿勢制御にとって重要な剛体モードの追従性を向 上させることはメリットがある.さらにノッチフィルター を利用した場合，制御系にとって関心がある制御帯域の位 相特性を比較的損なわないという利点がある .

その一方で, 一般に , ノッチフィルターによってカット する周波数帯域を広く設定すると光の外側の広範囲の周波 数帯域で位相の変化が生じるため, ノッチフィルターに よってカットする周波数帯域はなるべく狭く設定したいと いう事情がある．すなわち，ノッチフィルターを利用した 制御系はロバスト性が必ずしも高くなく，制御対象のモデ ルが不確かな場合には設計が困難を伴うことが多い，光の ため, ノッチフィルターは, システムの動特性を正確に同 定した上で設計するのが一般的である .ところが , 構造振 動の固有振動数はロケットに搭載するミッション機器の特 
宇宙技術 第 1 巻（2002 年）

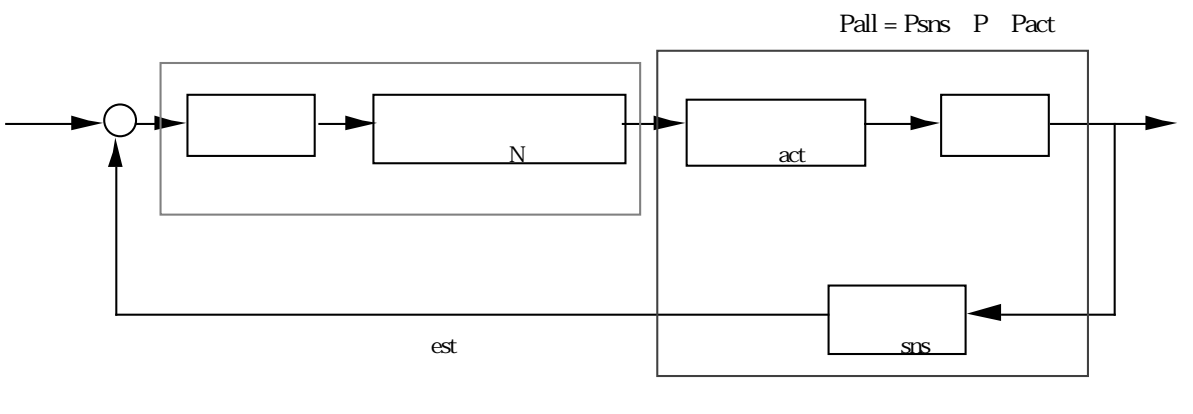

第4図 システムブロック図

性によっても変化し，さらに飛翔中時間とともに変化する 乥こで, 本稿では, 固有振動数へと適応的に収束するノッ チフィルターを考えた .すなわち , ノッチフィルターを利 用した従来の制御系で問題視されることがあったロバス卜 性を, 本稿で提案する制御系では適応型フィルターを用い ることで対応する .これは, 制御対象のモデルが不確かな 場合にも，より高い目標追従性と安定性を確保することを 意味する.

制御系のブロック図としては，第 4 図のような形式を仮 定した。制御器は, 通常の動的補償器 $C$ と適応型ノッチ

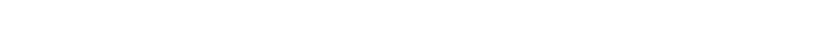
方は, 適応型ノッチフィルターが完全に構造 1 次振動モ一 ドを捉えていると仮定すれば，一般的な線形制御系の設計 法を用いて設計を実施できる．

3.1 ノッチフィルターの定式化 特定の周波数のゲ インを抑えるフィルターという意味でノッチフィルターに はいろいろなタイプが存在しうるが , ここでは以下のよう な形式のものを考える .

$$
\begin{array}{cl}
\dot{\boldsymbol{x}}(t)=\left[\begin{array}{ccc}
0 & -\omega & 0 \\
\omega & 0 & 0 \\
0 & 0 & 0
\end{array}\right] \boldsymbol{x}(t)+\left[\begin{array}{l}
k_{1} \\
k_{2} \\
k_{3}
\end{array}\right]\left(u(t)-\left[\begin{array}{lll}
1 & 0 & 1
\end{array}\right] \boldsymbol{x}(t)\right) \\
y(t)=\left[\begin{array}{lll}
0 & 0 & 1
\end{array}\right] \boldsymbol{x}(t) \\
\text { ただし, } \\
k_{1}, k_{2}, k_{3}, & : \text { 制御系設計定数 } \\
u(t) & : \text { フィルターへの入力 } \\
y(t) & : \text { フィルターからの出力 } \\
\boldsymbol{x}(t) & : \text { フィルターの状態変数 } \\
\dot{\boldsymbol{x}}(t) & : \boldsymbol{x}(t) \text { の時間微分 } \\
t & : \text { 時刻を表す変数 } \\
\text { ¿のプラス変換は } &
\end{array}
$$

$$
\begin{aligned}
& \boldsymbol{X}(s)=\frac{1}{s^{3}+\left(k_{1}+k_{3}\right) s^{2}+\omega\left(\omega-k_{2}\right) s+\omega^{2} k_{3}}\left[\begin{array}{c}
k_{1} s^{2}-k_{2} \omega s \\
k_{2} s^{2}+k_{1} \omega s \\
k_{3}\left(s^{2}+\omega^{2}\right)
\end{array}\right] U(s) \\
& Y(s)=\frac{k_{3}\left(s^{2}+\omega^{2}\right)}{s^{3}+\left(k_{1}+k_{3}\right) s^{2}+\omega\left(\omega-k_{2}\right) s+\omega^{2} k_{3}} U(s)
\end{aligned}
$$

となる.このとき，(2.2) 式で $s= \pm j \omega$ とおくと $Y(j \omega)=0$

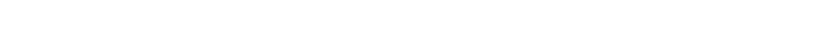
たしかに出力ゲインがゼロになることがわかる .このいを ノッチフィルターの中心周波数と呼ぶ .

$$
\begin{aligned}
& \text { こニで }, \\
& \boldsymbol{X}(s)=\left[\begin{array}{l}
X_{1}(s) \\
X_{2}(s) \\
X_{3}(s)
\end{array}\right]
\end{aligned}
$$

と定義すると，

$$
\begin{aligned}
& U(s)-X_{1}(s)-X_{3}(s)=\frac{s^{3}+\omega^{2} s}{s^{3}+\left(k_{1}+k_{3}\right) s^{2}+\omega\left(\omega-k_{2}\right) s+\omega^{2} k_{3}} U(s) \\
& k_{1} X_{2}(s)-k_{2} X_{1}(s)=\frac{\left(k_{1}^{2}+k_{2}^{2}\right) \omega s}{s^{3}+\left(k_{1}+k_{3}\right) s^{2}+\omega\left(\omega-k_{2}\right) s+\omega^{2} k_{3}} U(s)
\end{aligned}
$$

を得る.(4.1) 式, (4.2) 式より,

$$
\left(U(s)-X_{1}(s)-X_{3}(s)\right)=\frac{s^{2}+\omega^{2}}{\left(k_{1}^{2}+k_{2}^{2}\right) \omega}\left(k_{1} X_{2}(s)-k_{2} X_{1}(s)\right)
$$

となる .ここで , フィルターへの入力 $u(t)$ が周波数 $\omega_{0}$ の 正弦波であると仮定し，フィルターの定常状態を考える． すると，(5) 式より，(4.1) 式と（4.2）式の信号は両方とも 周波数 $\omega_{0}$ の正弦波となり，光のゲインの比は，

$$
\frac{\left\|\omega^{2}-\omega_{0}^{2}\right\|}{\left(k_{1}^{2}+k_{2}^{2}\right) \omega}
$$

で, 位相差は $\omega_{0}$ の方が大きいときは逆相 (180度ずれ) で， 逆に $\omega_{0}$ の方が小さいとき同相 (位相のずれは 0 度) となる .

これより，フィルターへの入力信号に乗っている周波数 $\omega_{0}$ と，フィルター係数 $\omega$ との関係は, (4.1) 式 , (4.2) 式の 信号を比較することで判別できることがわかる .3 .3 節で後 述するように，この性質を利用して，ノッチフィルター中 心周波数の適応則を構成することができる.

\section{2 動的補償器の設計 第 4 図の動的補償器 $C$ の} 設計について述べる.ここでは,(1) 式のような形式のノッ チフィルターを前提とし，このノッチフィルターの中心周 波数と構造 1 次振動の周波数が完全に一致していると仮定 する.この仮定の下, ノッチフィルター $C_{\mathrm{N}}$, アクチュエー 多特性 $P_{\mathrm{act}}$, 機体特性 $P$, センサ特性 $P_{\mathrm{sns}}$ をシリーズに連結 した線形システムに対して動的補償器 $C$ を設計した .ここ

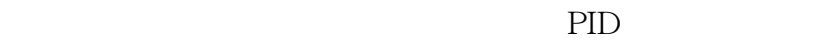
ボード線图を用いた古典制御理論により，設計を試みた 。 このとき，ノッチフィルターの係数 $k_{1}, k_{2}, k_{3}$ はPID制御器 のゲイン $k_{\mathrm{P}}, k_{\mathrm{I}}, k_{\mathrm{D}}$ と同樣に線形制御系の調整パラメータと して設計できる.設計したシステムの一巡伝達関数の例を 第 5 图に示す .この閉ループ制御系は安定である.設計し た仕樣の詳細は省略するが，基本的には古典制御理論によ 
動翼を用いた観測ロケットの適応型姿勢制御系の設計とハードウェア試験（澤井秀次郎・松田聖路）
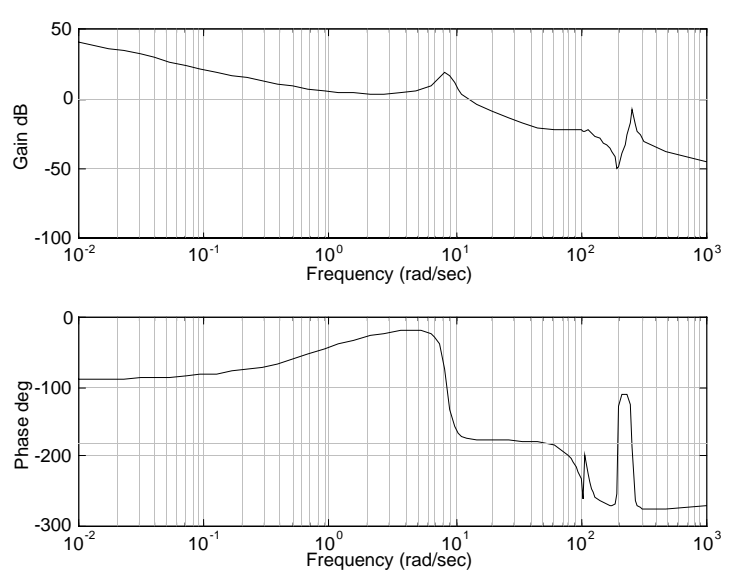

第 5 図 一巡伝達関数の周波数特性の設計例

り与えられている極配置の指針を確保しつつ, 低周波数帯 域での一巡伝達関数のゲインをなるべく高く維持している この例では,センサ・アクチュエータ特性を含めた機体の 動特性は

$$
P_{a l l}(s)=\frac{a_{6} s^{6}+a_{5} s^{5}+a_{4} s^{4}+a_{3} s^{3}+a_{2} s^{2}+a_{1} s+a_{0}}{b_{7} s^{7}+b_{6} s^{6}+b_{5} s^{5}+b_{4} s^{4}+b_{3} s^{3^{3}}+b_{2} s^{2}+b_{1} s+b_{0}}
$$

ただし，

$$
\begin{array}{ll}
a_{6}=-3.1961 \times 10^{1} & b_{7}=1.0000 \times 10^{0} \\
a_{5}=-1.8013 \times 10^{2} & b_{6}=1.0886 \times 10^{1} \\
a_{4}=-1.1766 \times 10^{6} & b_{5}=7.6652 \times 10^{4} \\
a_{3}=-6.5566 \times 10^{5} & b_{4}=3.6219 \times 10^{5} \\
a_{2}=3.3881 \times 10^{9} & b_{3}=7.3391 \times 10^{8} \\
a_{1}=2.3924 \times 10^{9} & b_{2}=8.9239 \times 10^{8} \\
a_{0}=-3.0540 \times 10^{-4} & b_{1}=5.1987 \times 10^{10} \\
& b_{0}=1.2987 \times 10^{-4}
\end{array}
$$

とした .これは動翼への舵角指令值に対するセンサ位置で のロケット姿勢の応答を示しており，S-520型ロケットで 典型的なユーザ・ペイロードを仮定した場合に動圧最大時 点 (打ち上げの 20 秒後) で予想されるピッチ軸・ヨー軸周 りの姿勢特性である．ロケットの場合，ピッチ軸周りと ヨ一軸周りの姿勢の特性が同一であることが多く，また

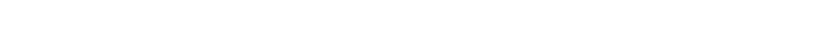
か軌道の誘導結果に直接関与しているため，重要視される．

第 5 図では ( 7 ) 式の特性を元に，

$$
\begin{aligned}
& \omega_{0}=105.5[\mathrm{rad} / s] \\
& {\left[\begin{array}{lll}
k_{1} & k_{2} & k_{3}
\end{array}\right]=\left[\begin{array}{lll}
63.3 & -0.6 & 1.0
\end{array}\right]} \\
& {\left[\begin{array}{lll}
k_{P} & k_{I} & k_{D}
\end{array}\right]=\left[\begin{array}{lll}
20.0 & 25.0 & 0.15
\end{array}\right]}
\end{aligned}
$$

と制御器のパラメータを設計している。なお，この制御器 のパラメータでノッチフィルターの中心周波数のみが時間 とともに変化し常に機体の構造 1 次振動数と一致している とすると, 打ち上げ直後 (打ち上げの 4 秒後 . 構造 1 次振 動数は $80.58[\mathrm{rad} / \mathrm{s}]$ ) の特性や中間的な時点 (打ち上げの 約 14 秒後. 構造 1 次振動数は $93.55[\mathrm{rad} / \mathrm{s}])$ の特性でも
システムは安定であることが確認されている .

なお，ここでは姿勢のひとつの方向成分のみを定式化し ている．しかし，実際のロケットでは姿勢の3 方向を制御 しているため，実際にはこれより複雑な制御系を構成する ことになる．ただし，各軸を独立に分解して制御指令を生 成する場合には，1軸周りの制御則で本質的な議論ができ る、特にロケットの場合，ピッチ軸周りやヨー軸周りは等 方的であることが多く，上記の制御系を両方の軸に独立に 設定できる．ロール軸に関しては, ロケットの場合, 軌道 の誘導結果に直接関係しないため, 一般に高い応答性は必 要とされない. 兴のような場合, ロール軸周りの姿勢制御 においては, 制御系の安定性を優先させたいわゆるゲイン 安定化で十分である.すなわち, ロール軸周り制御につい ては，高い応答性を目指した適応型ノッチフィルターを採 用する必要性は高くない 。

3.3 ノッチフィルターの中心周波数の適応則 前 節では, ノッチフィルターの中心周波数が構造 1 次振動 モードと一致していると仮定した .これは, 適応則により ノッチフィルターの中心周波数か構造 1 次振動モードへと 収束していくことが前提となる。乥こで, 本節で, (1) 式に より定式化されるフィルターの中心周波数 $\omega$ を構造 1 次振 動モードに適応させる方策を考える .ここで, 構造 1 次振 動モードの周波数は, フィルターへの入力の中で主要な振 動モードのひとつになると仮定する .この周波数を $\omega_{0}$ とお くと，フィルターが定常状態になったときは, $\omega \approx \omega_{0}$ とし て

$$
\begin{aligned}
\frac{u(t)-x_{1}(t)-x_{3}(t)}{k_{1} x_{2}(t)-k_{2} x_{1}(t)} & =\frac{\omega^{2}-\omega_{0}^{2}}{\left(k_{1}^{2}+k_{2}^{2}\right) \omega} \\
& =\frac{\left(\omega-\omega_{0}\right)\left(\omega+\omega_{0}\right)}{\left(k_{1}^{2}+k_{2}^{2}\right) \omega} \approx \frac{2\left(\omega-\omega_{0}\right)}{k_{1}^{2}+k_{2}^{2}}
\end{aligned}
$$

が成立する、これより，

$$
\begin{array}{r}
\frac{\partial \omega}{\partial t}=k_{4}\left(u(t)-x_{1}(t)-x_{3}(t)\right)\left(k_{1} x_{2}(t)-k_{2} x_{1}(t)\right) \\
\text { ただし, } \quad t(t)=\left[\begin{array}{lll}
x_{1}(t) & x_{2}(t) & x_{3}(t)
\end{array}\right]
\end{array}
$$

なる $\omega の$ 変更則を適用すると， $\omega \approx \omega_{0}$ のとき，

$$
\frac{\partial \omega}{\partial t} \approx \frac{2 k_{4}\left(\omega-\omega_{0}\right)}{k_{1}^{2}+k_{2}^{2}}\left\|k_{1} x_{2}(t)-k_{2} x_{1}(t)\right\|^{2}
$$

となり， $k_{4}<0$ であれば $\omega の$ 時間微分は常に $\omega_{0}$ に近づくよ うに作用することがわかる．

3.4 離散時間系での適応型ノッチフィルターの表現 以上の議論では, フィルターは連続時間系で表現されてい た。しかし，現実の搭載計算機への実装などを考えると， フィルターは離散時間系で定式化されている方か望ましい． そのため,ここでは適応型ノッチフィルターの離散時間系 表現を導出する. 導出された式は三角関数の計算を必要と しないため，高速処理が期待できる .

さて，まず離散時間系のサンプリング時間間隔を $\Delta t と し$ 
宇宙技術 第 1 巻（2002 年）

て ,(1) 式, (9) 式の離散時間での近似表現を

$$
\begin{gathered}
\boldsymbol{x}_{d}(k+1)=\left[\begin{array}{ccc}
\cos \omega(k) \Delta t & -\sin \omega(k) \Delta t & 0 \\
\sin \omega(k) \Delta t & \cos \omega(k) \Delta t & 0 \\
0 & 0 & 1
\end{array}\right] \boldsymbol{x}_{d}(k) \\
+\left[\begin{array}{c}
k_{1} \\
k_{2} \\
k_{3}
\end{array}\right] \Delta t\left(u_{d}(k)-\left[\begin{array}{lll}
1 & 0 & 1
\end{array}\right] \boldsymbol{x}_{d}(k)\right)
\end{gathered}
$$$$
y_{d}(k)=\left[\begin{array}{lll}
0 & 0 & 1
\end{array}\right] \boldsymbol{x}_{d}(k)
$$

$y_{d}(k)=\left[\begin{array}{lll}0 & 0 & 1\end{array}\right] \boldsymbol{x}_{d}(k)$

$\omega(k+1)=\omega(k)+k_{4} \Delta t\left(u_{d}(k)-\left[\begin{array}{lll}1 & 0 & 1\end{array}\right] \boldsymbol{x}_{d}(k)\right)\left[\begin{array}{lll}-k_{2} & k_{1} & 0\end{array}\right] \boldsymbol{x}_{d}(k)$

とおく.ただし,$d$ (下付の添え字) は離散時間系での表現 を表す .(11.1) 式の右辺第 2 項はゼロ次ホールド型の積分 で近似されている.ここで，

$$
\begin{aligned}
& p(k) \equiv \cos \omega(k) \Delta t \\
& q(k) \equiv \sin \omega(k) \Delta t
\end{aligned}
$$

とおくと，(11.1) 式は，

$$
\boldsymbol{x}_{d}(k+1)=\left[\begin{array}{ccc}
p(k)-q(k) & 0 \\
q(k) & p(k) & 0 \\
0 & 0 & 1
\end{array}\right] \boldsymbol{x}_{d}(k)+\left[\begin{array}{l}
k_{1} \\
k_{2} \\
k_{3}
\end{array}\right] \Delta t\left(u_{d}(k)-\left[\begin{array}{llll}
1 & 0 & 1
\end{array}\right] \boldsymbol{x}_{d}(k)\right)
$$

となる .ここで， $\omega$ の更新量が小さいとき，

$$
\begin{aligned}
& \sin (\omega(k+1)-\omega(k)) \Delta t \approx k_{4} \Delta t^{2} \Delta v_{d}(k) \\
& \cos (\omega(k+1)-\omega(k)) \Delta t \approx 1
\end{aligned}
$$

ただし，

$$
\Delta v_{d}(k) \equiv\left(u_{d}(k)-\left[\begin{array}{lll}
1 & 0 & 1
\end{array}\right] \boldsymbol{x}_{d}(k)\right)\left[\begin{array}{lll}
-k_{2} & k_{1} & 0
\end{array}\right] \boldsymbol{x}_{d}(k)
$$

より（11.3）式は近似的に

$$
\begin{aligned}
& p(k+1)=p(k)-q(k) k_{4} \Delta t^{2} \Delta v_{d}(k) \\
& q(k+1)=q(k)+p(k) k_{4} \Delta t^{2} \Delta v_{d}(k)
\end{aligned}
$$

となる .これより, 適応型のノッチフィルターの離散時間 表現は, (13) 式, (11.2) 式, (14.1) 式, (14.2) 式によっ て表されることがわかる .

フィルターの係数 $k_{1} \sim k_{4}$ について考察する $. k_{1}, k_{2}, k_{3}$ は ノッチフィルターとのものの係数であり，前節のように， たとえばボード線図を参照することで決定できる．これに 対して $k_{4}$ は適応則の係数であり，一般的な線形制御理論の 設計法は存在しない。しかし，(10）式より

$$
\frac{\omega(k+1)-\omega(k)}{\Delta t} \approx \frac{2 k_{4}\left(\omega(k)-\omega_{0}\right)}{k_{1}{ }^{2}+k_{2}{ }^{2}}\left\|\left[\begin{array}{llll}
-k_{2} & k_{1} & 0
\end{array}\right] \boldsymbol{x}_{d}(k)\right\|^{2}
$$

となるので，

$$
k_{4}=-\frac{k_{1}^{2}+k_{2}^{2}}{2 \Delta t\left\|\left[\begin{array}{lll}
-k_{2} & k_{1} & 0
\end{array}\right] \boldsymbol{x}_{d}(k)\right\|^{2}}
$$

と設定することで 近似的に $\omega(k+1) \approx \omega_{0}$ が成立することが わかる.ここで，右辺の絶対值は，入力 $u(t)$ の振動成分
の振幅とほぼ比例する項であり定数ではない，炎のため， (16) 式のままでは , $k_{4}$ は時間とともに変化することになる が , フィルターを現実のハードウェアに実装する際には， $\mathrm{k}_{4}$ は定数であることか望ましい. 弚こで，(16) 式を時間に 関して定数化することを考えた．

状態量 $x(t)$ の第 1 項 , 第 2 項の振幅を $A$ とすると，(16) 式は，

$$
\begin{aligned}
k_{4} & =-\frac{k_{1}^{2}+k_{2}^{2}}{2 \Delta t\left\|\sqrt{k_{1}^{2}+k_{2}^{2}} A \sin \left(\omega_{0} t_{k}+\phi\right)\right\|^{2}} \\
& =-\frac{1}{2 \Delta t\left\|A \sin \left(\omega_{0} t_{k}+\phi\right)\right\|^{2}}
\end{aligned}
$$

となる．ただし， $\varphi$ は時刻原点に依存した位相差を表す定 数である .ここで, ノッチフィルターへの入力 $u(t)$ に含 まれる構造 1 次振動周波数の振幅を $\mathrm{A}_{\mathrm{u}}$ とする .このとき， ノッチフィルター中心周波数が構造 1 次振動周波数と一致 していると，(2.1) 式より $A_{u}=A$ が成立する .これより， $k_{4}$ の値として ，

$$
k_{4}=-\frac{1}{2 \Delta t A_{u}^{2}}
$$

が指標となる.ただし，実際には $\mathrm{A}_{\mathrm{u}}$ は定数ではなく，また (18) 式の導出の前提となっている（10）式はノッチフィル ターか定常状態に落ち着いていることを仮定しているため， 現実には最適な $k_{4}$ の值が $(18)$ 式から一意に定まるとは限 らない.実際，(15) 式からも明らかなように， $k_{4}$ の絶対値 を大きく設定しすぎると中心周波数が $\omega_{0}$ を挟んで振動的な ふるまいをする．このため， $k_{4}$ の值は現実には（18）式な どを参照しつつ小さめの絶対值を設定することか望ましい .

\section{5 適応型ノッチフィルターを実装する際の注意点} 以上, 適応型ノッチフィルターの定式化を行った .しかし， これらの議論では, 非線形動的システムとしてのフィル ターの安定性を厳密には証明できていない.ただし，ノッ チフィルター中心周波数のずれなどによって構造 1 次振動 モードが不安定化すると, 光れに対応した振動の振幅が大 きくなる．このとき，(8) 式等より（11.3）式の修正則にお いて, 構造 1 次振動モ一ドの影響が支配的となることがわ かる.これは, ノッチフィルターの中心周波数は期待通り に適応していくことを意味する．すなわち，初期段階で ノッチフィルターの中心周波数のずれに起因して構造 1 次 振動モードが不安定的なふるまいをしても, 弚れが顕在化 するに従い適応する速度が大きくなるため, 適応則は構造 1 次振動モードを正確に捉えるようになる，という特徵を 有する .これは, ノッチフィルター中心周波数のずれに よってシステムが不安定化すると，(15) 式の右辺の絶対值 部分が大きくなるため, 左辺の適応速度が早くなることか らも理解される．逆に，たとえノッチ中心周波数が一致す べき周波数とずれていても, 出力で光の周波数が励起され ていない場合には適応則は動作しない．これは，このモー ドが安定化し, 収束していくに従い, 適応則が機能しなく なっていくことを示す．収束した後に適応則が機能する必 要はなく，これは安定性・ロバスト性の面からは望ましい． 
動翼を用いた観測ロケットの適応型姿勢制御系の設計とハードウェア試験（澤井秀次郎・松田聖路）

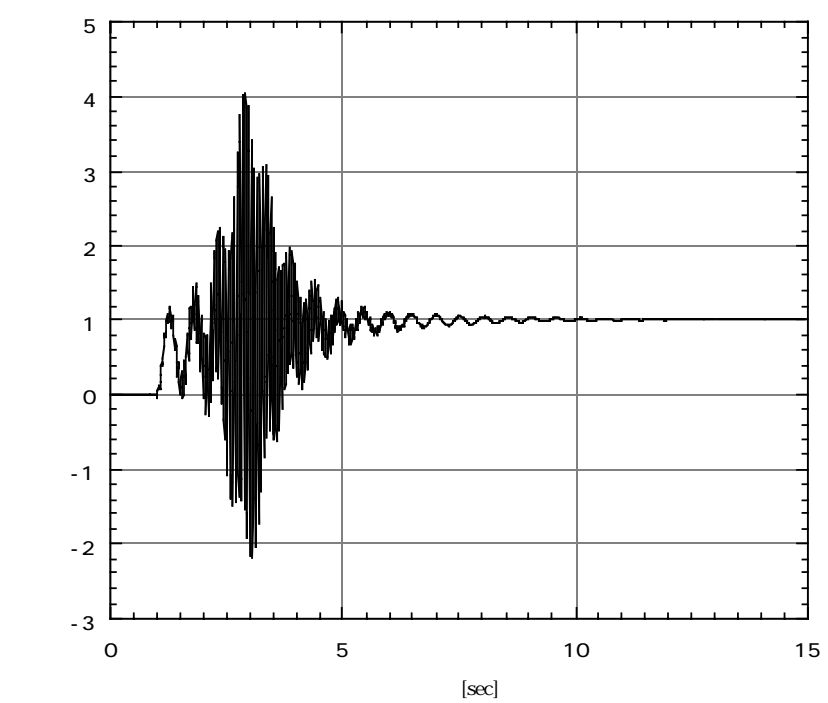

(1) 機体の応答

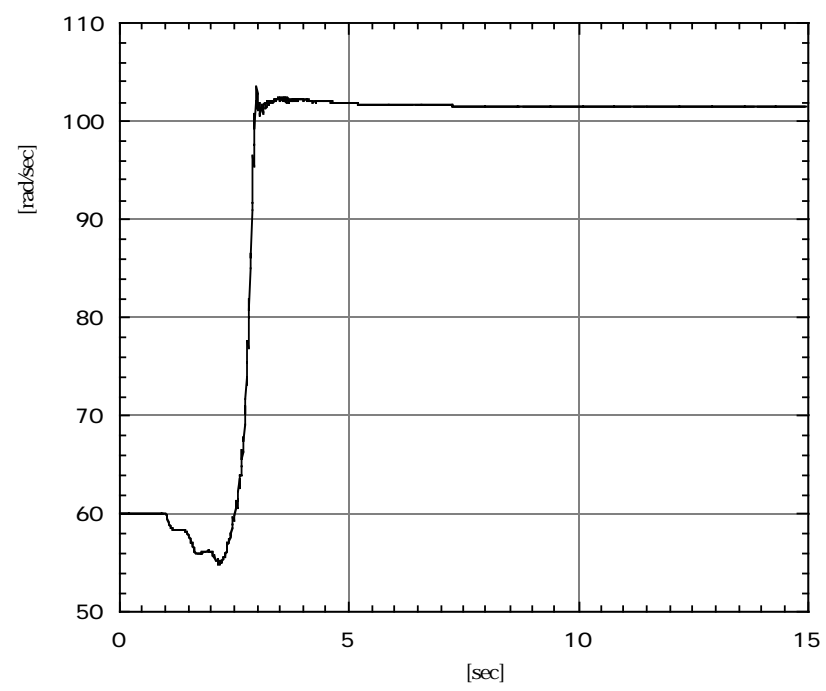

（2） 中心周波数の適応

第6 図＼cjkstart適応型ノッチフィルターによる制御のシミュレーション例

ただし，これは全ての制御対象に対して常に安定性が成 立することを述べるものではない . 特に , 複数の振動モ一 ドの固有周波数がお互いに近接している場合には必ずしも 上記の論理が成立するとは限らない. 厳密な安定性を議論 するためには，個々のケースに対して，制御対象の特性を 考慮してリアプノフの安定定理を適用するなどの方策が必 要である.

なお，適応則への入力に複数の周波数の波が混在する場 合 , 現実には , ノッチフィルターでカットすることを期待 している構造 1 次振動モードが存在しうる周波数帯域を予 め予想し , 何らかの処置を行うべきである .もっとも単純 には,たとえばノッチフィルターの中心周波数か湾化しう る範囲を規定し弚こから逸脱しないようにガードをする， という処置があるが, この他, 適応則に使用する信号にバ ンドパスフィルターをかけることで関心のある周波数のみ を抽出する方法もあり得る.すなわち, (4.1) 式, (4.2) 式 で表されるような信号を谷のまま掛け合わせるのではなく，

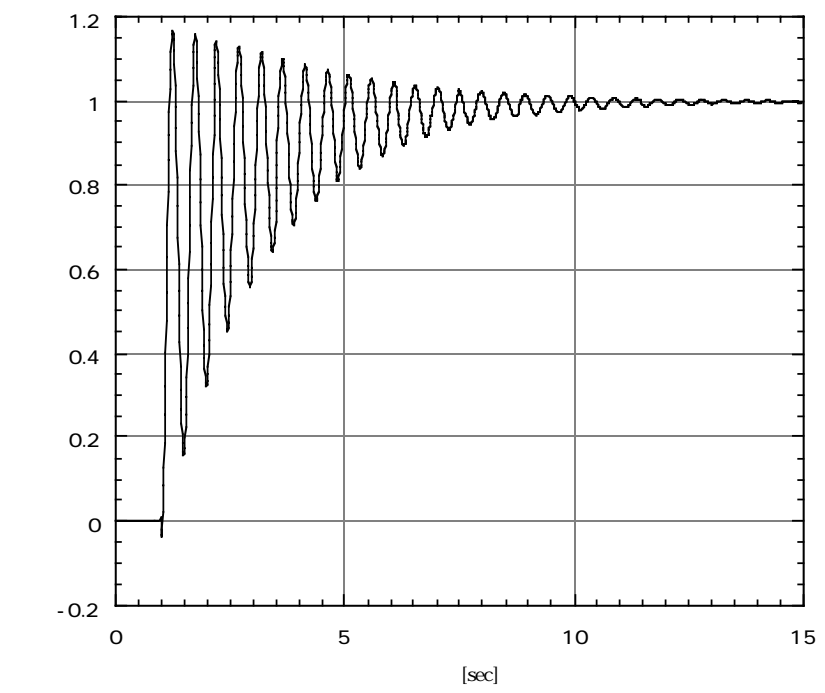

（1） ノッチフィルター中心周波数 $101.7 \mathrm{rad} / \mathrm{s}$ の場合

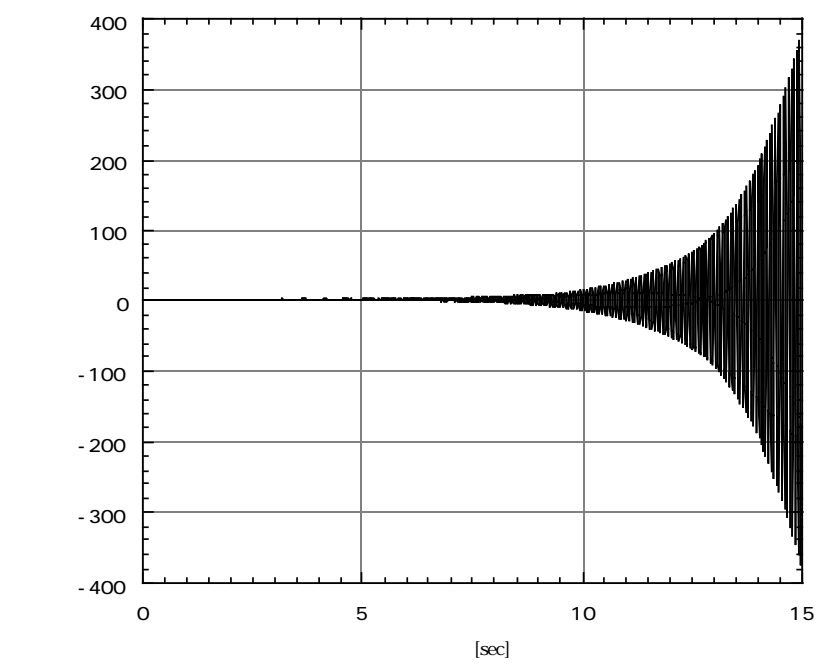

（2）ノッチフィルター中心周波数 $60.0 \mathrm{rad} / \mathrm{s}$ の場合 第 7 图 非適応型ノッチフィルターによる制御のシミュレーション例

バンドパスフィルターを通して構造 1 次振動モード近傍の 周波数域のみを取り出すことも考えられる.この場合， (4.1) 式, (4.2) 式の両方の信号に同一特性のフィルターを 通せば , バンドパスフィルターによる位相の変化は気にす る必要はない，ただし，これらの方策を利用しても，構造 1 次振動モードが存在しうる周波数帯域に他の振動モード が混在する場合には対応できないが，本稿で実装を仮定し ている S-520 型観測ロケットの場合には, 構造 1 次振動 モードに近い周波数の振動モードは存在しない .

\section{4. 制御系の検 証}

以上の議論を検証する目的で数值シミュレーションを実 施した .ここで扱うシステムは 3.2 節のようなものとし，光 のようなシステムで, シミュレーション開始 1 秒後に目標 姿勢角がステップ状に変化するとした .さらに, 制御器は サンプリング時間間隔が 0.01 秒の離散時間系とし，適応型 ノッチフィルターは,(13) 式,(11.2) 式, (14.1) 式, (14.2) 
宇宙技術

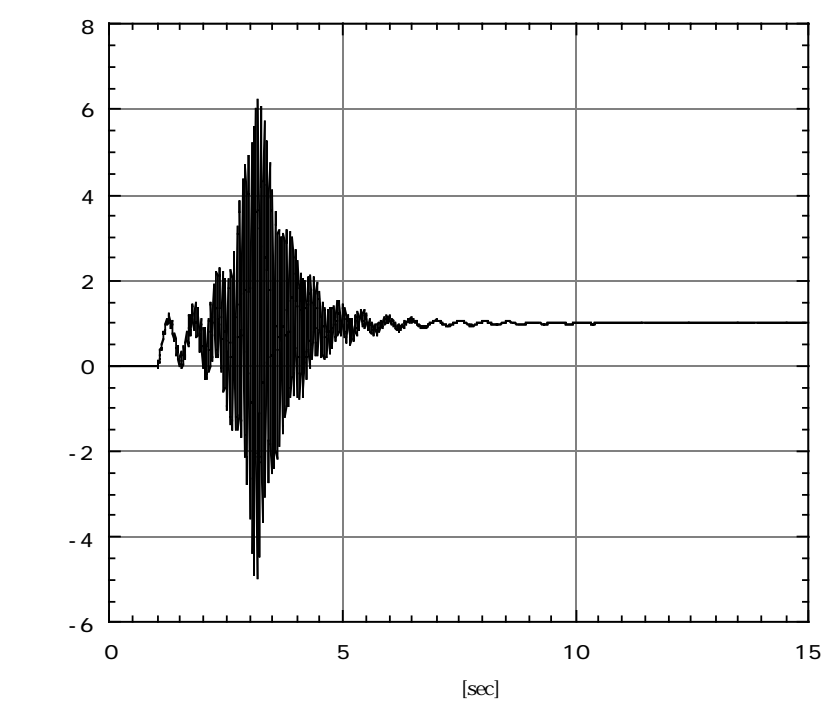

(1) 機体の応答

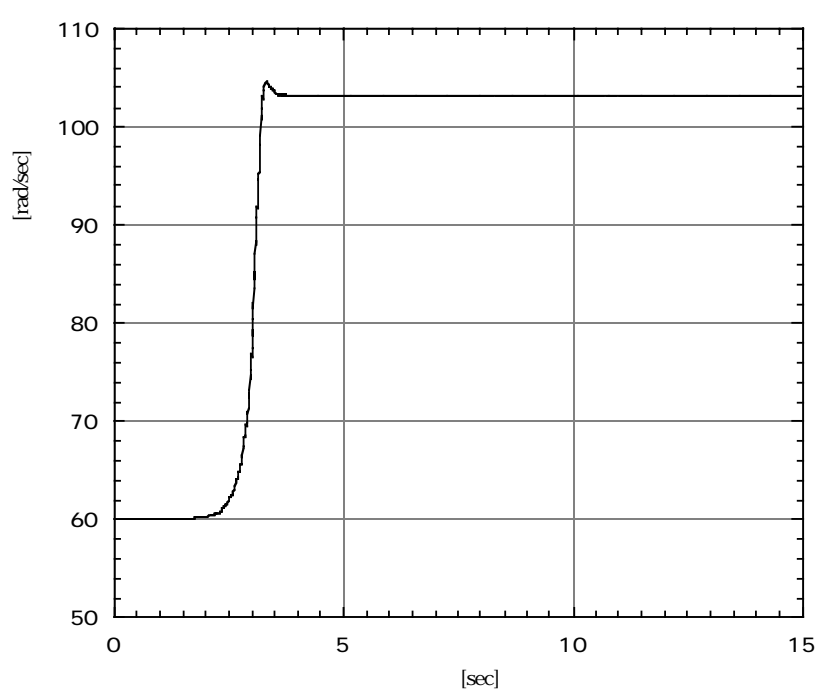

（2） 中心周波数の適応の樣子

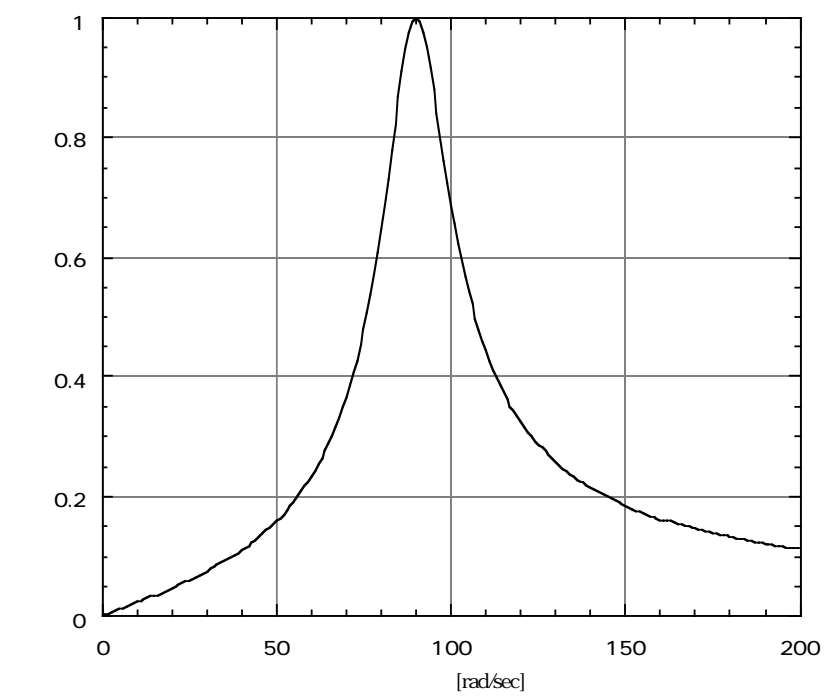

（3）使用したバンドパスフィルターの特性

第 8 图 バンドパスフィルター付き適応型ノッチフィルターを用いた 機体制御のシミュレーション例
第 1 巻 （2002 年）

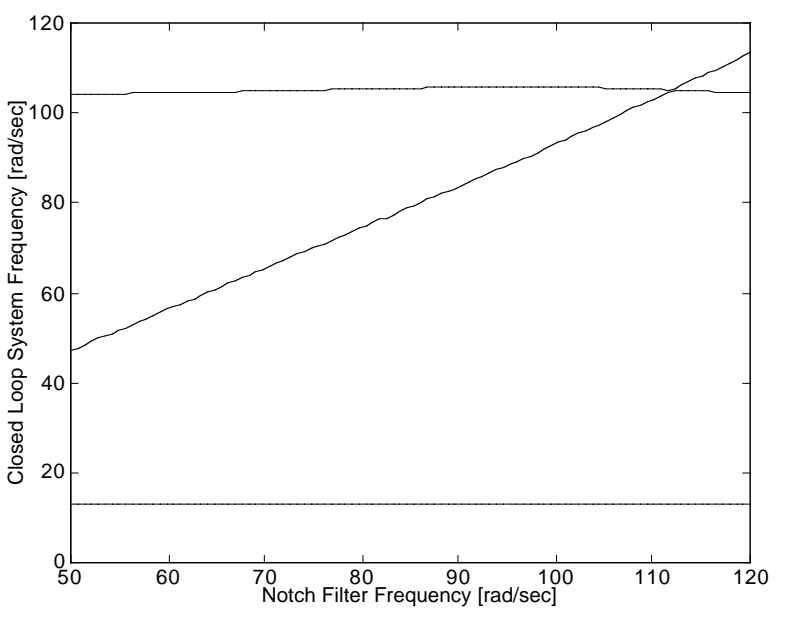

第 9 図 ノッチフィルター中心周波数に対する 閉ループ系固有振動数の変化

式で表されるとした . 第6 図にシミュレーション結果例を 示す .この例では , ノッチフィルターの適応則にかかわる 係数 $k_{4}$ は， $k_{4}=-0.1\left[\mathrm{rad}^{3}\right]$ と設定しており，また，初期 のノッチフィルター中心周波数は, 構造 1 次振動モードの


フィルターに関わる係数は 3.2 節に記されている通り，

$$
\left[\begin{array}{lll}
k_{1} & k_{2} & k_{3}
\end{array}\right]=\left[\begin{array}{lll}
63.3 & -0.6 & 1.0
\end{array}\right]
$$

と置いた.図より,ステップ状の目標值変化が入るまでは， ノッチフィルター中心周波数は変化しないが, 目標值変化 を受けて機体振動が発生するとともに適応則が機能し始め， 約 3 秒間で $101.7 \mathrm{rad} / \mathrm{s}$ に収束していることがわかる . 比 較のため, 第 7 図にノッチフィルターの中心周波数か変化 しない場合の応答を掲げた .この图は第6図（1）と比較さ れるべきものである.第7図（1）では，ノッチフィルター 中心周波数が最初から適応則の収束先であるから 101.7 $\mathrm{rad} / \mathrm{s}(=16.2 \mathrm{~Hz})$ であった場合の機体の応答を示してい る.第6 図 (1) の適応型ノッチフィルターでの応答に比べ て過渡応答が小さく，また周波数 $2.1 \mathrm{~Hz}$ の剛体モードの 他，目立つ振動モードがない.これに対して，第7図 (2)で はノッチフィルター中心周波数が適応則の初期值である $60.0 \mathrm{rad} / \mathrm{s}$ か変化しなかった場合の機体の応答を示して いる.このとき，系は約 $16 \mathrm{~Hz}$ の振動の振幅が発散的に大 きくなっている樣子がわかる .このとき , ノッチフィル ターの中心周波数が構造 1 次振動の周波数とずれているた め, この部分が不安定化している。これより，適応型ノッ チフィルターを用いた制御器は, あわせるべき中心周波数 が固定の場合に比べ, 安定性の確保に効果があることがわ かる、なお，第6図（1）のシミュレーションケースは，中 心周波数の初期推定誤差か極端に大きい例と考えられる .

第6図（2）は, 中心周波数が適応していく樣子を示して いるが，これを見ると，目標姿勢角がシミュレーション開 始 1 秒後にステップ状に変化しているのに対応して中心周 波数か変化を開始しているが, 初期の頃に収束値と逆向き に動作しており，また产の後も振動的樣子が見て取れる． 
動翼を用いた観測ロケットの適応型姿勢制御系の設計とハードウェア試験（澤井秀次郎・松田聖路）

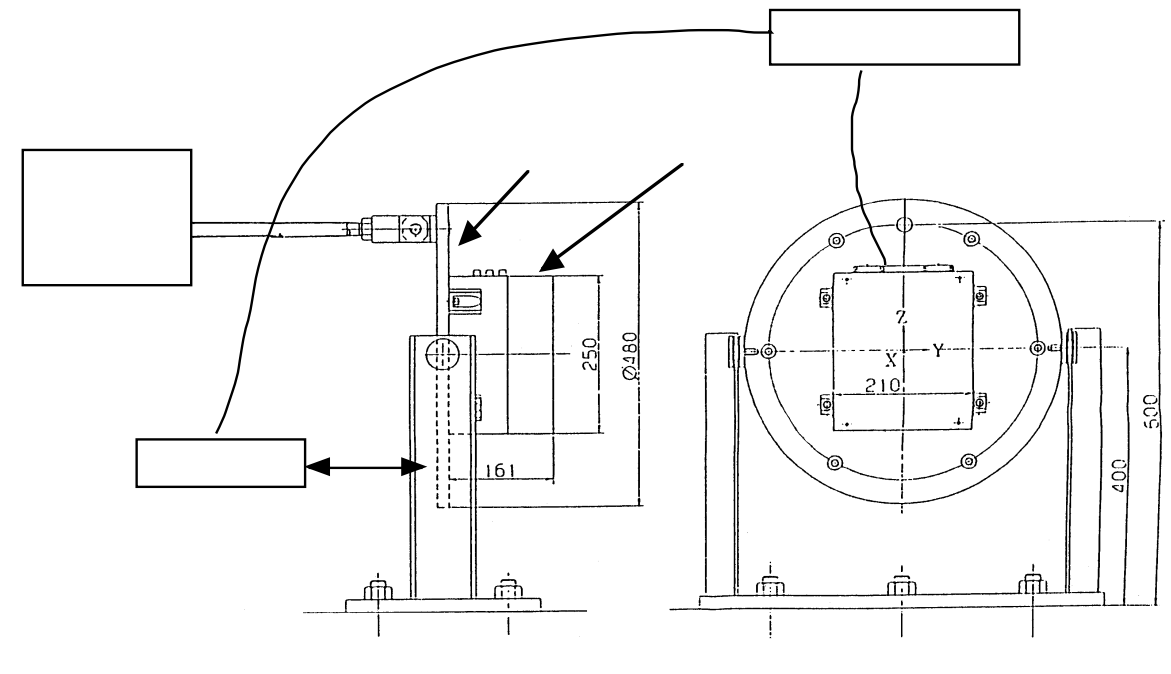

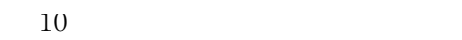

この原因としては, 適応則 (14.1) 式, (14.2) 式への入力 信号である

$$
\begin{aligned}
& v_{1}(k) \equiv u_{d}(k)-\left[\begin{array}{lll}
1 & 0 & 1
\end{array}\right] \boldsymbol{x}_{d}(k) \\
& v_{2}(k) \equiv\left[\begin{array}{lll}
-k_{2} & k_{1} & 0
\end{array}\right] \boldsymbol{x}_{d}(k)
\end{aligned}
$$

に構造 1 次振動モード以外の周波数の信号が存在している ためと考えられる . 乥こで, 構造 1 次振動以外の信号の影 響を低減するため, バンドパスフィルターを利用したノッ チフィルター中心周波数の適応則を適用した 具体的には， (19) 式の信号 $v_{1}(k), v_{2}(k) に$

$$
P_{\mathrm{BPF}}(s) \equiv \frac{2 \zeta \omega_{\text {cent }} s}{s^{2}+2 \zeta \omega_{\text {cent }} s+\omega_{\text {cent }}{ }^{2}}
$$

ただし，ろ：濾波帯域を定める定数

$$
\omega_{\text {cent }} \text { : 中心周波数の初期推定值 }
$$

なる特性のバンドパスフィルターを通したものをv $v_{1}^{\prime}(k), v_{2}^{\prime}(k)$ とおき，(14.1) 式，(14.2) 式の代わりに, 適応則を

$$
\begin{aligned}
& p(k+1)=p(k)-q(k) k_{4} \Delta t^{2} v_{1}^{\prime}(k) v_{2}^{\prime}(k) \\
& q(k+1)=q(k)+p(k) k_{4} \Delta t^{2} v_{1}^{\prime}(k) v_{2}^{\prime}(k)
\end{aligned}
$$

とした .

バンドパスフィルターの特性として,$\zeta=0.1 ， \omega_{\text {cent }}=90$

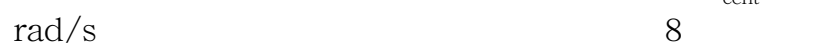
第 8 図 (2) より, 中心周波数の適応則は, バンドパスフィ ルターを利用しない第6図（2）の場合よりも滑らかである ことがわかる.ここで, 第 8 図 (2) では中心周波数の収束 先は, $103.2 \mathrm{rad} / \mathrm{s}$ であった . 構造 1 次振動モードの真值 $105.5 \mathrm{rad} / \mathrm{s}$ に対して , 若干のずれがあるのみならず , 第 6 图（2）の $101.7 \mathrm{rad} / \mathrm{s}$ とずれがあった .ただし，中心周 波数が構造 1 次振動モードの周波数とずれているものの第 6図 (1), 第8図 (1) より，系はどちらの中心周波数でも安 定であることがわかる. 中心周波数の適応則は, 構造 1 次 振動モードが励起されることによって動作するように意図 されており，制御系が安定でこのモードが収束した場合に は，中心周波数は更新されなくなることを意味する．すな
わち，構造 1 次振動モードに厳密に一致していなくても， 光の時点で制御系が安定であれば啇応則は光の場で更新し なくなる可能性があることを示唆している.第8図（3）に は，使用したバンドパスフィルターの特性を示している． 今の場合, 剛体モードは10〜20 rad/sの帯域に存在してい るが, このバンドパスフィルターにより，この帯域のゲイ ンは 0.1 倍以下であることがわかる.

第9図に,閉ループ系でのシステム固有振動数を示す .こ こで横軸はノッチフィルターの中心周波数である. 構造 1 次振動モードに相当するモードは閉ループ系ではほぼ 100〜105 rad/sにあることがわかる.ノッチフィルターの 中心周波数はこのモードに適応していったと考えられる なお，図中，ほぼ線形に変化する周波数モードがあるが, こ れはノッチフィルター产のものの固有振動数に対応してい る.すなわち，このモードは制御器ローカルのモードであ る。

\section{5. ハードウェア試験による検証}

以上のような適応型ノッチフィルターを利用した制御器 を，観測ロケットの姿勢制御システムに適用するため， ハードウェアを試作した ここで試作したハードウェアは， 特別な追加なしに宇宙科学研究所のS-520型観測ロケット に搭載することを目標としている．このため，試作した ハードウェアに対して，環境試験，電気的整合性試験を含 む各種の試験を実施したが , 本節では実装したノッチフィ ルター制御システムが構造振動に適応していくことを確認 することを目的に実施した摇動試験について述べる．

摇動試験の試験コンフィギュレーションを第 10 図に示 す . 慣性航法センサを含む姿勢制御装置は正弦波状に振動 する摇動台に載せられている．摇動台は加振機により，指 令された周波数で摇動する .これにより，実際のセンサを 所望の周波数で振動させることができる.この加振の周波 数はレーザ変位計を用いた計測により観測される.試験で は, このレーザ変位計の出力と供試体である姿勢制御装置 の出力をペンレコーダで記録した .この試験は, 適応型 

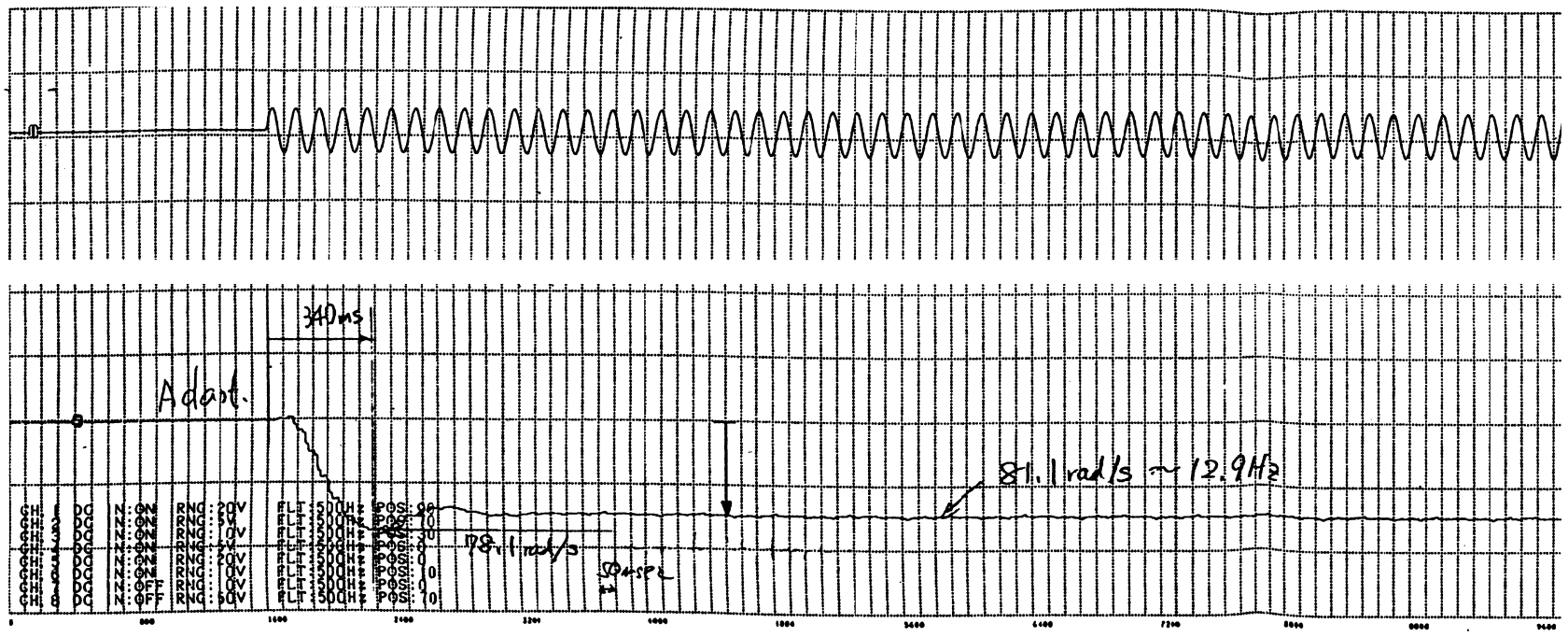

第 11 図 ハードウェア摇動試験の結果例

ノッチフィルターの中心周波数がこの周波数に収束するこ とを確認することを目的としているため, 加振する周波数 はロケットの構造 1 次振動モード周波数を意識することに した .

第11図に試験結果の例を掲げる .この例では摇動台を周 波数81 rad/sで摇動したときの摇動台の振動軌跡とノッチ フィルターの中心周波数の变化を示す . 第 11 図の上の図 は、レーザ変位計の出力であり、摇動台の振動の樣子を表 す.姿勢制御装置を含む摇動台は正弦波状に $81 \mathrm{rad} / \mathrm{s}$ で摇 動されている．下の図は姿勢制御装置出力のうち，ノッチ フィルター中心周波数の現在值の電圧出力をプロットして いる . 初期の中心周波数 $100.5 \mathrm{rad} / \mathrm{s}(=16 \mathrm{~Hz})$ が、摇動 開始後約 $340 \mathrm{msec}$ で一旦 $78.1 \mathrm{rad} / \mathrm{s}$ まで下振れした後， 約 $700 \mathrm{msec} て ゙ 81.1 \mathrm{rad} / \mathrm{s}$ に収束している.前節の数値シ ミュレーションよりも収束時間が早いのは, 励振している 振動の振幅の差が原因と考えられる . というのも，ハード ウェア実験では中心周波数の適応にかかわらず入力信号は 振幅一定の正弦波で与えているのに対して, 前節の数値シ ミュレーションではノッチフィルターの中心周波数が適応 していくに従い系が安定化し振動が収まっていっている． 中心周波数の適応速度は振幅に依存し，振幅が大きい方が 適心速度は速い．これが，ハードウェア実験で中心周波数 の収束が早かった原因と考えられる。

\section{6. ま と め}

以上, 動翼を用いた観測ロケット姿勢制御への応用を前 提とした適応型フィルター構造を有する制御器について論 じた . 数值シミュレーションなどにより, 提案する制御器 の有用性か確認された .ただし , 適応制御系の安定性につ いては, 制御対象との干渉を含めた非線形動的システムと しての厳密な証明は実施していない . 数值シミュレーショ ン例からもわかる通り, 適応則による中心周波数の収束先 は一意ではなく，制御系が安定となった時点で適応が終了 する．これは実用的には問題とはならないが，一方で，リ
アプノフ関数を用いた安定性の証明を困難にしている . 安 定性の証明については, 現実の搭載ロケットが確定した段 階で光のロケット固有の特性を考慮して検証する必要があ る.なお，制御系を現実の口ケットに実装する際，安定性 を確認する場合, リアプノフ関数を見つけだす努力をする よりも，むしろ広範な数值シミュレーションにより検証す ることも多い．というのも，現実のロケットの特性は非線 形の時変系であるため, これを直接扱い, 現実のセンサ ハードウェアなどの特性も線形モデルなどを利用せず直接 扱う方が結果として信頼性が確保される場合も多い.

現実のロケットの打ち上げにおいて構造振動周波数など はペイロードに依存して変化するが, 本稿で提案するよう な制御器を使用することにより, 制御器の再設計を行うこ となく樣々な打ち上げに供することができるようになると 期待される．著者らは，ここで提案した適応型制御器を組 み込んだ動翼システムを試作し，実機への搭載を念頭に各 種試験を終了している．本稿で提案した制御器を組み込ん だ動翼システムは実際のフライトに供せる段階にある .

\section{参 考 文 献}

1) SESデータセンター編: 観測ロケット飛翔実験報告書 ( $\mathrm{S}-520-17$ 号機·S-520-19号機), 宇宙科学研究所, SES-TD-00-008, 2001.

2) SESデータセンター編 : 観測機ユーザーズハンドブック , 宇宙科 学研究所, SES-TD-83-008, 1983.

3) Kawaguchi, J., Sawai, S., Yamakawa, H. and Matsuda, S. : S520-\#18 Canard Control Using Adaptive Notch Filter, Proc. ISAS 4th Workshop on Astrodynamics and Flight Mechanics, 1994, pp.175-179.

4) Kawaguchi, J., Sawai, S. and Matsuda, S. : S-520-\#18 Design of Canard Control System, Proc. ISAS 5th Workshop on Astrodynamics and Flight Mechanics, 1995, pp.223-228.

5) Kawaguchi, J., Nakatani, I., Morita, Y., Matsuo, H., Okaya, S. and Hayashi, F. : On the M-V Attitude Control System Part I, Proc. 18th International Symposium on Space Technology and Science, 1992, pp.979-984. 